\title{
ANALYSIS OF FISH SUPPLY CHAINS IN TOMINI BAY AREA, INDONESIA
}

\author{
Miru Sulaeman*, Kornelius Yobert, Darman \\ Faculty of Economics, University of Tadulako, Indonesia \\ *E-mail: sulaimanmiru@yahoo.co.id
}

\begin{abstract}
This study aims to analyze the fish supply chain system in the Tomini Bay region, Indonesia. This research utilized survey methods based on fish supply chains. The results of the study found that there were 3 parts of the fish supply chain, namely fishing boats (fishermen) - fish landing bases (traders) - fish terminals (consumers). The furthest distance in the supply chain is the Fish Landing Base (FLB) Pagimana at $528 \mathrm{Km}$ with a travel time of 11 hours 25 minutes. The closest distance is the Petapa FLB at $75.8 \mathrm{Km}$ with a travel time of 2 hours 1 minute. This distance and travel time are the obstacles to the fish supply chain from Tomini Bay to the fish terminal. This condition causes fish quality loss and has an impact on the low community in the Tomini Bay region.
\end{abstract}

\section{KEY WORDS}

Supply chain, fisheries, Tomini Bay, Central Sulawesi.

Tomini Bay is the biggest bay in the equatorial region with an area of $59,500 \mathrm{~km}^{2}$ or \pm 6 million hectares, with very large potential natural resources. Tomini Bay's east borders the Maluku Sea, while the Northeast borders the Sulawesi Sea. In biodiversity distribution area, this area is in the zone of Wallacea, which historically is a separate region of the Asia and Australia Continents. Tomini Bay administratively covers four regencies in central Sulawesi (Muzakir and Suparman, 2016).

Tomini Bay has very large fisheries potential, especially aquaculture and marine capture fisheries. Nevertheless, its potential has not been utilized optimally for the community welfare around the Tomini Bay area. Population poverty rate is $9.20 \%$ (Banggai Regency); 18.15\% (Tojo Una-Una Regency); 17.16\% (Poso Regency); 17.55\% (Parigi Moutong Regency). Overall the number of poor people is $14.14 \%$ in Central Sulawesi (Statistics of Central Sulawesi Province, 2018).

It is necessary to optimize the management of fisheries resource potential in Tomini Bay. Optimization of fisheries potential management could be done through the concept of supply chain systems. A supply chain system is a tool to integrate the efficiency of suppliers, companies, distributors, retailers, to ensure these tools can produce and deliver products with the right amount, location and time (Indrajid and Djokopranoto, 2002). A good fisheries supply chain system may improve the efficiency and effectiveness of fisheries potential management. Therefore it can improve the community welfare in the Tomini Bay region.

Therefore, this study aims to analyze the fish supply chain. The fisheries supply chain system is believed to be one of the efforts to improve the welfare of the population in the Tomini Bay region.

\section{LITERATURE REVIEW}

Supply chain management is the synchronization process of companies, suppliers, and customers to match the flow of materials, services, and information based on customer demand (Krajewski, et al, 2010). A supply chain system is a tool to integrate the efficiency of suppliers, companies, distributors, retailers, to ensure equipment can produce and deliver products with the right amount, location, and time to increase satisfaction in customer service (Indrajid and Djokopranoto, 2002).

Geary et al. (2002) suggest that uncertainty in a supply chain can stem from consumer, supplier, process and control demands. Uncertainty originating from consumer demand and 
related to lead time, both from suppliers and customers, are the sources of dissatisfaction between elements in the supply chain. Therefore, these two sources of uncertainty need to be managed well to ensure the element relationships in the supply chain remain stable in order to increase or maintain the level of service to consumers.

Pujawan (2005) stated that supply chain management is a network of companies that work together to create and deliver a product to the end user. These companies usually include suppliers, factories, distributors, stores or retail, as well as supporting companies, such as logistics services companies.

Chapman et al. (2002) suggested that supply chain risk management focuses on how to understand and overcome chain effects when a large or small accident occurs at a point in the supply network.

\section{METHODS OF RESEARCH}

This study used survey methods through direct observation in fish landing bases in the Tomini Bay region. Tomini Bay region consists of 4 districts, namely Banggai, Tojo Una-Una, Poso, and Parigi Moutong. Supply chain analysis of capture fisheries is carried out in stages based on the fishing line to the final destination.

\section{RESULTS AND DISCUSSION}

Tomini Bay is the largest fish supplier in Central Sulawesi. Marine capture fisheries production in Central Sulawesi is 174,964 tons and $38.1 \%$ of them comes from Tomini Bay. Fish production in Tomini Bay Region is 66,348 tons with the following details:

Table 1 - Production of Marine Fishing in the Tomini Bay Area

\begin{tabular}{|c|c|c|}
\hline \multicolumn{2}{|c|}{ Regions } & Production (Tons) \\
\hline 1 & Banggai & $14.986,40$ \\
\hline 2 & Tojo Una-Una & $9.023,80$ \\
\hline 3 & Poso & $27.358,70$ \\
\hline 4 & Parigi Moutong & $14.979,10$ \\
\hline \multicolumn{2}{|c|}{ Total } & $66.348,00$ \\
\hline
\end{tabular}

Source: Statistics of Central Sulawesi Province, 2018.

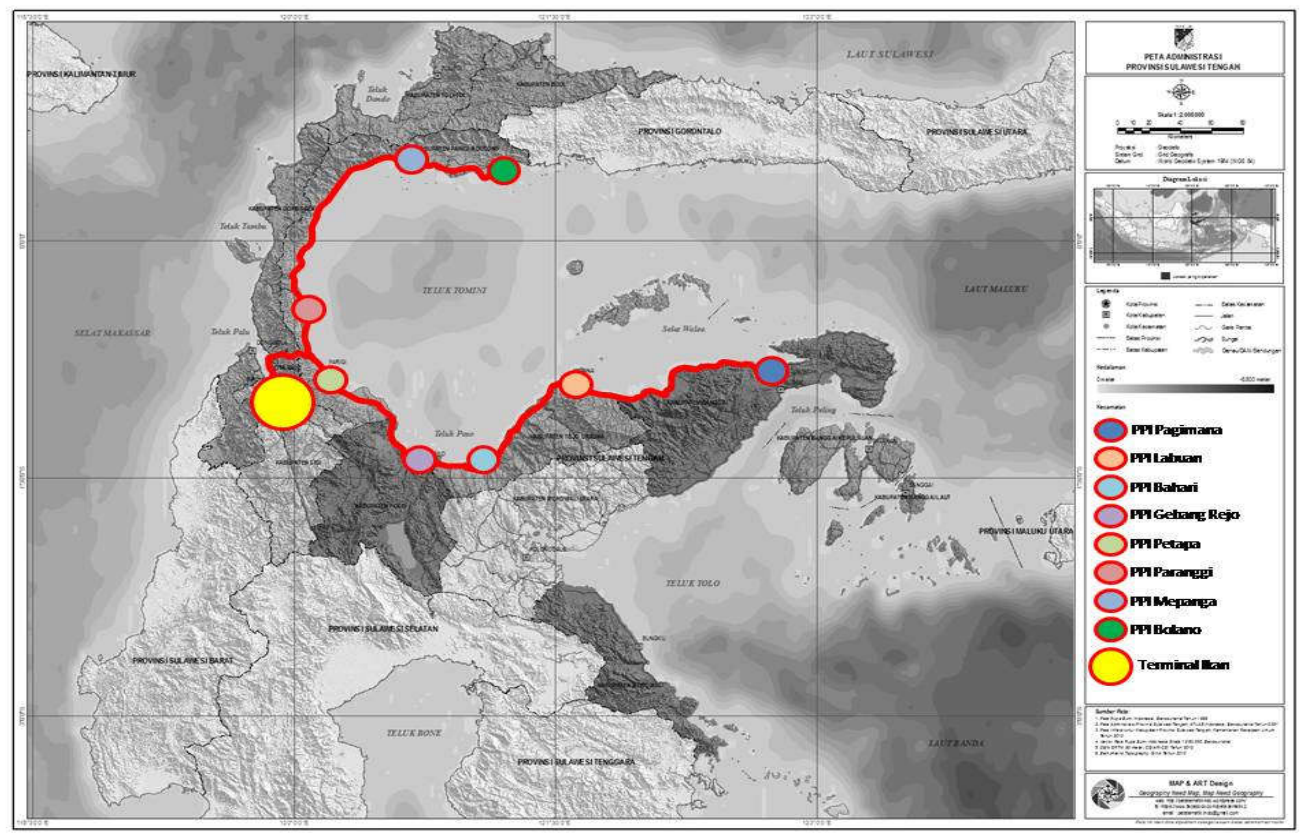

Figure 1 - Fish Landing Base in Tomini Bay Region (Source: Survey data, 2018) 
Fish catches in Tomini Bay land at each Fish Landing Base (FLB) port. There are 8 ports in the Tomini Bay region which are spread in 4 districts. Pagimana FLB (Banggai), Labuan FLB and Bahari FLB (Tojo Una-Una), Gebang Rejo FLB (Poso), Petapa FLB, Labuan FLB, Mepanga FLB, Petapa FLB, Paranggi FLB, Mepanga FLB, and Bolano FLB (Parigi Moutong).

There are 8 points of FLB fish suppliers to the fish terminal in Palu City. FLB terminal is the last fish auction place before it is distributed to the market. The distance between FLB and fish terminal is far enough to be the cause of the loss of fish value. Especially if there is a road repair in the coffee plantation area which is the only access to the fish terminal. The normal distance and travel time from FLB to the fish terminal are described as follows:

Table 2 - Fish Production in the Tomini Bay Region

\begin{tabular}{|c|c|c|c|c|}
\hline \multicolumn{2}{|c|}{ Fish port } & \multicolumn{2}{|c|}{ FLB to Fish Terminal } & \multirow{2}{*}{ Regions } \\
\cline { 3 - 5 } & Mileage $(\mathrm{km})$ & Traveling time (Hours: Minute) & Banggai \\
\hline 1 & Pagimana FLB & 528 & $11: 25$ & Tojo Una-Una \\
\hline 2 & Labuan FLB & 371 & $8: 13$ & Tojo Una-Una \\
\hline 3 & Bahari FLB & 265 & $5: 58$ & Poso \\
\hline 4 & Gebang Rejo FLB & 215 & $4: 50$ & Parigi Moutong \\
\hline 5 & Petapa FLB & 75,8 & $2: 01$ & Parigi Moutong \\
\hline 6 & Paranggi FLB & 95,9 & $2: 23$ & Parigi Moutong \\
\hline 7 & Mepanga FLB & 274 & $5: 54$ & Parigi Moutong \\
\hline 8 & Bolano FLB & 308 & $6: 38$ & \\
\hline
\end{tabular}

Source: Survey Data, 2018.

The furthest distance is Pagimana FLB which is $528 \mathrm{Km}$ with a travel time of 11 hours 25 minutes. The closest distance is the Petapa FLB as far as $75.8 \mathrm{Km}$ with a travel time of 2 hours 1 minute. Distance and travel time become obstacles to the fish supply chain from Tomini Bay to the fish terminal, which causes the loss of fish value. Based on the results of the field survey, the marine capture fisheries supply chain system in the Tomini Bay region is described as follows:

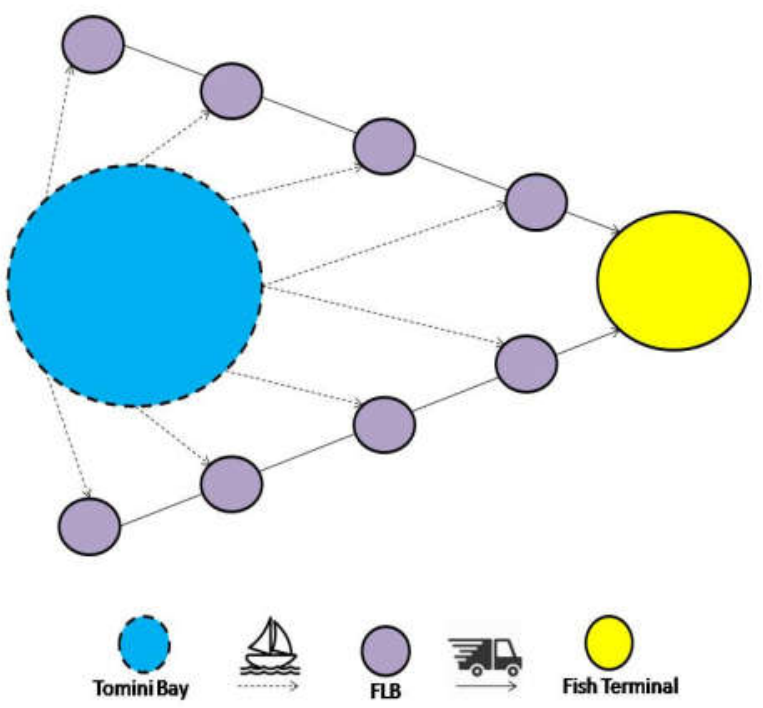

Figure 2 - Fish Supply Chain Systems in Tomini Bay Region (Source: Survey Data, 2018)

There were 3 parts of the fish supply chain, namely fishing boats (fishermen) - fish landing bases (traders) - fish terminals (consumers). Fish supply chains in the Tomini Bay region are inefficient due to distance and travel time, hence reducing fish value. Therefore, a cold chain system is needed to maintain fish quality to ensure there is no quality loss in fish value which causes a decrease in the selling price. 


\section{CONCLUSION}

Tomini Bay is the largest fish supplier in Central Sulawesi. Fish production in Central Sulawesi is 174,964 tons and $38.1 \%$ of Tomini Bay. There are 8 ports in the Tomini Bay region in 4 districts. Pagimana FLB (Banggai), Labuan FLB and Bahari FLB (Tojo Una-Una), Gebang Rejo FLB (Poso), Petapa FLB, Parabi FLB, Mepanga FLB, and Bolano FLB (Parigi Moutong). There are 3 parts of the fish supply chain, namely fishing boats (fishermen) - fish landing bases (traders) - fish terminals (consumers). The fish supply chain in Tomini Bay is inefficient due to distance and travel time which causes the loss of fish value. Therefore a cold chain system is needed to maintain fish quality.

\section{REFERENCES}

1. Muzakir \& Suparman. 2016. The strategy of Developing Tomini Bay or Economic Growth of Coastal Community in Central Sulawesi, Journal of Economics and Policy, Vol 9 (1) (2016): 96-110

2. Statistics of Central Sulawesi Province. 2018. Central Sulawesi in Figure 2018, PaluCentral Sulawesi

3. Indrajid, R. R. \& Djokopranoto. 2002. Supply Chain Management Concept: A New Way to Look at the Supply Chain of Goods. Grasindo, PT Gramedia Widiasarana Indonesia Publisher, Jakarta.

4. Krawjeski, R. \& Malhotra. 2010. Operation Management, Processes and Supply Chains, Ninth Edition. UK: Pearson.

5. Geary, S., Childerhouse, P., \& Towill, D. 2002. Uncertainty and the seamless supply chain. Supply Chain Management Review 6 (4), 52-60.

6. Pujawan. 2005. Supply Chain Management, One Edition. Surabaya: Guna Widya.

7. Chapman, P., Christopher, M., Juttner, U., Peck, H., \& Wilding, R. 2002. Identifying and managing supply chain vulnerability. Logistics \& transport focus: The Journal of the Institute of Logistics and Transport 4: 59-64. 